\title{
Estimating Wildlife Harvest Based on Reported Consumption by Inuit in the Canadian Arctic
}

\author{
Tiff-Annie Kenny ${ }^{1}$ and Hing Man Chan ${ }^{1,2}$
}

(Received 12 May 2016; accepted in revised form 25 July 2016)

\begin{abstract}
The harvest and consumption of wildlife are integral to the livelihood, culture, and nutritional status of the Inuit of northern Canada. When wildlife populations are perceived to be vulnerable, harvest restrictions may be enacted to protect species conservation interests. Such restrictions may also have consequences for the nutrition and food security of Inuit communities. This study aims to estimate the harvest numbers of key wildlife species needed to sustain the traditional diet of Inuit. Using responses to the food frequency questionnaire that were collected from 806 men and 1275 women during the Inuit Health Study of 2007-08, we characterized annual country food consumption in five Inuit regions of northern Canada. Data on average edible yield of food species and Inuit population demographics were compiled and used to estimate the total number of harvested animals. Caribou (Rangifer tarandus) was the species consumed with the highest prevalence (>90\%) and in greatest amounts $(29.6-122.8 \mathrm{~kg} / \mathrm{person} / \mathrm{yr})$, depending on sex and region. The annual consumption rate for beluga whale (Delphinapterus leucas) was 5.9-24.3 kg per person, depending on sex and region, and that for ringed seal (Pusa hispida) was $4.1-25.0 \mathrm{~kg}$ per person. To sustain this consumption rate, it is estimated that a mean total of 36526 caribou, 898 beluga whales, and 17465 ringed seals are required annually. These results provide a baseline for food security and resource management in the Canadian Arctic to balance Indigenous subsistence needs and wildlife conservation.
\end{abstract}

Key words: Inuit health survey; Canada; subsistence harvest; country food; nutrition; caribou; ringed seal; beluga; food security

RÉSUMÉ. La prise et la consommation de gibier font partie intégrante du mode de vie, de la culture et de l'alimentation des Inuits du Nord canadien. Lorsque certaines espèces sont perçues comme vulnérables, des restrictions peuvent être mises en vigueur quant à leur capture afin de favoriser leur protection et leur conservation. Par le fait même, ces restrictions peuvent avoir des conséquences sur l'alimentation et la sécurité alimentaire des collectivités inuites. Cette étude tente d'estimer les prises d'importantes espèces nécessaires au soutien du régime alimentaire traditionnel des Inuits. À l'aide des résultats découlant du sondage relatif à la fréquence de consommation des aliments réalisé auprès de 806 hommes et de 1275 femmes dans le cadre de l'Étude sur la santé des Inuits en 2007-2008, nous avons caractérisé la consommation annuelle de nourriture de campagne dans cinq régions inuites du nord du Canada. Les données concernant le rendement comestible moyen des espèces alimentaires et les caractéristiques démographiques de la population inuite ont été compilées et utilisées pour estimer le nombre total d'animaux capturés. Le caribou (Rangifer tarandus) était l'espèce la plus souvent consommée (> $90 \%)$ et en plus grandes quantités (de 29,6 à 122,8 kg/personne/année), en fonction du sexe de la personne et de la région. Le taux de consommation annuel du béluga (Delphinapterus leucas) était de 5,9 à 24,3 $\mathrm{kg}$ par personne, en fonction du sexe et de la région, tandis que celui du phoque annelé (Pusa hispida) était de 4,1 à 25,0 $\mathrm{kg}$ par personne. Pour soutenir ce taux de consommation, on estime qu'il faut annuellement un total moyen de 36526 caribous, de 898 bélugas et de 17465 phoques annelés. Ces résultats servent de point de référence à la gestion de la sécurité alimentaire et des ressources dans l'Arctique canadien afin d'équilibrer les besoins de subsistance indigènes et la conservation de la faune.

Mots clés : sondage sur la santé des Inuits; Canada; prises de subsistance; nourriture de campagne; alimentation; caribou; phoque annelé; béluga; sécurité alimentaire

Traduit pour la revue Arctic par Nicole Giguère.

\section{INTRODUCTION}

The Arctic is populated by several key species of mammals, e.g., caribou (Rangifer tarandus), beluga whale (Delphinapterus leucas), and ringed seal (Pusa hispida), whose population health is increasingly threatened by the pervasive influence of human activities and climate change (Kutz et al., 2013). The Arctic is also inhabited by northern peoples, such as the Inuit, for whom the harvest and consumption of local wildlife, termed "country food," have provided subsistence for thousands of years (Nuttall et al., 2005). Inuit communities have witnessed a general decline

\footnotetext{
${ }^{1}$ Department of Biology, University of Ottawa, 30 Marie Curie, Ottawa, Ontario K1N 6N5, Canada

${ }^{2}$ Corresponding author: laurie.chan@uottawa.ca

(C) The Arctic Institute of North America
} 
in the health and population status of many wildlife species relevant to subsistence lifestyles (Kilabuk, 1998; Campbell, 2007; Dumond, 2007). Although the observed population declines have been attributed to various factors, including climate, habitat degradation, prevalence of disease and parasites, level of predation, and harvest, wildlife management regimes have often focused on quota and other non-quota harvest restrictions to conserve the wildlife species. Harvest restrictions have been implemented for various Canadian Arctic species. This includes harvest restrictions for caribou on Nunavut's Southhampton Island and most of the Qikiqtaaluk region (Government of Nunavut, 2015a, b), as well as in Nunatsiavut, where the George River caribou herd has declined by over $80 \%$ in the last decade (Government of Newfoundland and Labrador, 2013). Additionally, quota systems have been implemented for the harvest of beluga whale, narwhal (Monodon monoceros), bowhead whale (Balaena mysticetus), walrus (Odobenus rosmarus), and polar bear (Ursus maritimus) in various Inuit regions (Gosselin et al., 2002; Stewart and Lockhart, 2005).

The threats of climate change and habitat loss or degradation and the observed declines in species abundance have motivated a number of domestic and international conservation measures, implemented through agreements, legislation, and management regimes, to protect several key species of Arctic mammals (e.g., the polar bear). The precautionary approach (avert risks of serious or irreversible harm in the absence of scientific certainty) is increasingly accepted as a basic principle of environmental management and has been incorporated into various instruments of biodiversity conservation at national and international levels (Cooney, 2004). Although "intuitively sensible," reconciling the interests of biodiversity conservation and human livelihoods through a precautionary approach raises significant equity issues and can yield negative impacts on those intimately dependent on biological resources to support their livelihoods (Cooney, 2004).

Although harvest restrictions have often been implemented for wildlife populations perceived to be vulnerable, they have not always been supported by scientific evidence (Diduck et al., 2005). Quota systems have also had mixed success in achieving conservation objectives (Wilder, 1995). For some Canadian Arctic wildlife species, we lack the data on population status, health, and seasonal range needed for effective harvest management (Dumond, 2007). Furthermore, the degree to which Aboriginal subsistence harvests impose population stress on wildlife species has not to our knowledge been explicitly defined in the literature for the Inuit context. For some species, like beluga whales in the Inuvialuit Settlement Region, the total Inuit harvest has been deemed far below the magnitude at which negative population outcomes would be observed (DFO, 2000).

While the effectiveness of quota systems in conserving wildlife populations remains unclear, the consequences of restricting Inuit subsistence harvests are apparent. The harvesting and consumption of local wildlife by Inuit contributes importantly to physical health, food security, cultural identity, and spiritual well-being (Borré, 1991; Condon et al., 1995; Kuhnlein et al., 2004; Lambden et al., 2007). Country food contributes significantly to nutritional status: up to $25 \%$ higher intakes of protein are reported on days when country food is consumed, along with higher intakes of micronutrients (niacin, riboflavin, vitamin B6, B12, selenium, zinc, iron, phosphorous) and lower intake of carbohydrates and saturated fat, compared to days when country food is not consumed (Kuhnlein and Receveur, 2007; Blanchet and Rochette, 2008; Egeland et al., 2011). Country foods have been identified as preferable to market foods not only for their rich nutritional qualities, but also for their affordability, palatability, and importance to Inuit culture and identity (Borré, 1991; Wein and Freeman, 1992; Condon et al., 1995). Harvest restrictions are likely to exacerbate food insecurity - an issue identified in $62.6 \%$ of Inuit households by the Inuit Health Survey (Huet et al., 2012) - with implications for diet quality and risk of dietrelated chronic diseases.

Wildlife managers and Inuit community organizations need to interpret the projected outcomes of various management regimes and implement actions to buffer against any adverse effects on the needs of stakeholders involved. It is in this respect that, despite their "constitutionally entrenched" rights to harvest (Hummel and Ray, 2008), Indigenous communities may find that wildlife management regimes do not always account for their food security and nutritional status adequately.

Preserving the integrity of Indigenous food systems, their cultural institutions, and the traditional knowledge embedded within them involves recognition by wildlife managers that humans are an integral part of the ecosystem (Chapin et al., 2004). Implementing conservation policies and practices that reconcile the sometimes conflicting values of conserving wildlife and using wildlife for subsistence is challenging (Bennett et al., 2007). Although the sustainability of wildlife populations is relevant to both government (for wildlife management, public health, and nutrition) and Inuit beneficiaries, Inuit disproportionately experience the consequences of conservation measures and wildlife population threats. In allocating harvest quotas and enacting harvest regulations, managers should consider that Inuit require access to these resources to maintain adequate nutrition and food security: without wildlife resources, they become susceptible to the adverse outcomes of consuming market foods with low nutrient density (Kuhnlein et al., 2004; Egeland et al., 2011). Inuit land-claim agreements include extensive articles that detail wildlife harvesting rights for Inuit and standards for government restrictions on harvest. For instance, Article 5 (Wildlife) of the Nunavut Land Claims Agreement established harvesting rights, priorities, and privileges and a system of wildlife management in the Nunavut Settlement Area (Nunavut Final Agreement, 1993). Inuit have the right to harvest a stock or population up to the full level of their 
economic, social, and cultural needs. As part of the wildlife co-management process, an annual allowable harvest for selected species may be established (Natcher et al., 2012).

To develop conservation programs that optimize wildlife population sustainability while mitigating adverse effects on the quality of the Inuit diet, Inuit community organizations, wildlife managers, and public health professionals need reliable data on current harvest levels and how they are related to the diet. Unfortunately, few data sets are available to relate harvest levels to consumption levels in different regions of the Arctic. This study aims to establish estimates of country food use for selected species of wildlife (prioritized by their significance in the Inuit diet and data availability) in five Inuit regions of Canada. Translating dietary data on country food consumption into the equivalent wildlife harvest requirement situates issues of food security within a forum that is relevant to communities, wildlife managers, and public health and nutrition professionals.

\section{STUDY POPULATION AND LOCATION}

Country food consumption data used in this study were derived from the Canadian International Polar Year Inuit Health Survey (IHS). Conducted between the late summer and fall of 2007 and 2008, the IHS collected comprehensive baseline data about the health, and living conditions, of Inuit adults across three jurisdictions within the Canadian Inuit Nunangat (Inuit regions of Canada): Nunatsiavut, Nunavut, and the Inuvialuit Settlement Region (ISR) (Fig. 1). In accordance with survey design, separate results from Nunavut's three administrative regions (Kivalliq, Qikiqtaaluk, and Kitikmeot) are also presented. Nunavik (northern Quebec) Inuit were not included in the 2007-08 IHS because a separate health study had been conducted in Nunavik in 2004 (Rochette and Blanchet, 2007). The complete study design and methods for the IHS have been described elsewhere (Saudny et al., 2012). Briefly, a cross-sectional study was conducted in which 2796 households were randomly selected to participate. Inuit adults aged 18 and older from these households, both men and non-pregnant women, were eligible to participate. The Inuit Health Survey was designed in a participatory manner, with representatives from the three participating Inuit jurisdictions. It was approved by both the McGill University Faculty of Medicine Institutional Review Board and the University of Ottawa Health Sciences and Science Research Ethics Board (file number H05-15-16).

In total, 2595 adults from 1901 households $(68 \%$ of households approached) took part in the IHS, yielding a participation rate of about $12 \%$ of people from each community. The survey employed a number of methods (e.g., questionnaires, clinical tests, blood samples); however, this study includes only data from the food frequency questionnaire. Completed food frequency questionnaires were available from 208 men and 304 women in Kivalliq,

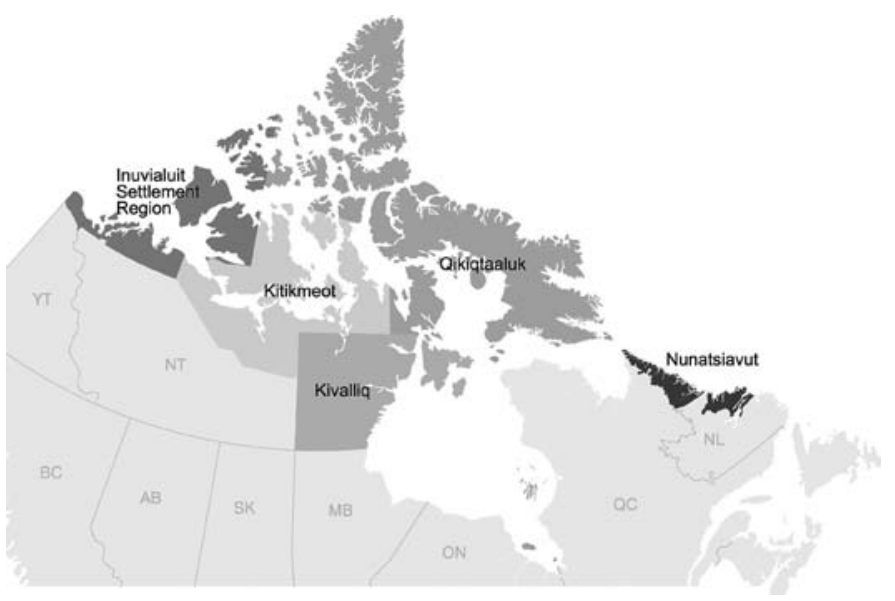

FIG. 1. Map showing the Inuit regions that participated in the Inuit Health Survey of 2007-08. (From west to east): the Inuvialuit Settlement Region; Kitikmeot, Kivalliq, and Qikiqtaaluk, the three subregions of Nunavut; and Nunatsiavut. Adapted from the Map of Inuit Nunangat (https://www.itk. ca/maps-of-inuit-nunangat) and used with permission of the Inuit Tapiriit Kanatami (ITK).

271 men and 412 women in Qikiqtaaluk, 143 men and 215 women in Kitikmeot, 86 men and 180 women in the ISR, and 98 men and 164 women in Nunatsiavut. Not all respondents reported consumption of beluga whale, ringed seal, or caribou. The subset of consumers (defined as those reporting $>0 \mathrm{~g}$ of a particular country food per day) for each species of country food was retained for analysis of harvest requirements.

\section{METHODS}

\section{Determination of Harvest Requirement}

To estimate the harvest of country foods necessary to meet current regional diets in the Canadian Arctic, we compiled data regarding Inuit country food consumption, Inuit population demographics, and the average edible yield of species consumed as country food. Data regarding the consumption of country foods were derived from the food frequency questionnaire of the IHS. The questionnaire, in English and Inuit languages, was filled out by the interviewer. It solicited information regarding the frequency, usual serving size, and seasonal variability of a comprehensive and locally adapted list of country foods. Participants were asked to recall how often each food item was consumed both "in season" and "out of season" in the previous year. These season designations were based on harvest calendars previously completed in the community (such as the Nunavut Wildlife Harvest Survey). We recorded frequency as per day, per week, per month, or per season and calculated the average consumption over the last year. Serving sizes were estimated using graduated, three-dimensional food model kits from Santé Québec, as well as pictures when needed. We focused on consumption of caribou, beluga whale, and ringed seal because of their 
importance in the Inuit diet. Only data from consumers, defined as individuals who reported consuming more than $0 \mathrm{~g} /$ day of a particular country food, were included in the analysis.

Annual consumption rate (g/year) from the previous year was calculated by multiplying the average annual food frequency (servings per year) by the average serving size (g/serving). Participants were asked to estimate typical serving sizes using standard portion models (Santé Québec) and pictures. Annual amounts of different body parts from each species were summed to estimate the total weight of that species consumed over the past 12 months; e.g., total caribou consumption $(\mathrm{kg} /$ person/year) is the sum of caribou meat + caribou organs + caribou fat + other parts consumed in that year. As food frequency data were not collected for children, we estimated consumption of children aged $0-12$ years (inclusive) at one-third of an adult equivalent, and that of adolescents (13-17 years) at two-thirds of an adult equivalent (Berkes and Farkas, 1978).

Employing a proportional projection, we adjusted the results from the IHS to estimate the total Inuit consumption of each country food by region. In brief, the calculated annual per capita consumption ( $\mathrm{kg} /$ person/year) and the consumption response rate (\# of consumers/total respondents), were multiplied by the estimated Inuit adult population (Table 1). This calculation was done separately for males and females, and the products were summed to obtain the total projected consumption.

$$
Y_{i}=\left(y_{i} * N\left(\frac{c_{i}}{n}\right)\right)_{f}+\left(y_{i} * N\left(\frac{c_{i}}{n}\right)\right)_{m}
$$

where $\mathrm{Y}_{i}=$ estimated regional consumption ( $\mathrm{kg} / \mathrm{region} /$ year) of country food species ' $i$ '; $y_{i}=$ reported per capita consumption ( $\mathrm{kg} /$ person/year) of country food species ' $i$,' by sex; $N=$ estimated Inuit population in the region (total regional population reported in 2011 census, multiplied by the percent respondents in the 2006 census identifying as Aboriginal), by sex; $n=$ total number of respondents to the IHS food frequency questionnaire in the region, by sex; $c_{i}=$ reported number of consumers ( $>0 \mathrm{~g}$ /day) of country food ' $i$ ' reported in the IHS by region and sex, for $f=$ females, and $m=$ males.

We repeated this process for each species (caribou, beluga whale, ringed seal) and again for consumption by children and adolescents. Total child, adolescent, and adult results were summed for each species, to yield an estimated annual consumption by region ( $\mathrm{kg} /$ region).

The total regional consumption of country food $(\mathrm{kg} /$ region/year) was then converted into subsistence harvest estimates (animals/region/year) on the basis of the average edible weight of each species. No universal standard of reference exists regarding the average edible yield of northern-harvested animals because of insufficient field studies, regional and seasonal weight variations, and challenges related to defining "edible" portions, since such definitions are culture-specific and not universal (Usher, 2000; Ashley, 2002). We derived our wildlife edible weight estimates from a review of literature, considering the strength of the study methods, the year in which the study was published, and the study location. We converted the total regional consumption ( $\mathrm{kg} /$ region/year) to harvest requirements (total number of animals required to meet present Inuit diets in each region) by dividing the total projected regional consumption by the most appropriate edible weight yield values reported in the literature (Table 2).

\section{Assumptions}

Several assumptions were made in the derivation of regional estimates. Whenever there was a range of values in the literature, we tended to use the parameters that would yield the most conservative estimate. Interpretation of the results presented here must therefore be considered within the constraints of these assumptions.

First, the edible weight yields used to translate total regional consumption ( $\mathrm{kg} /$ region) to wildlife harvest equivalents (number of animals harvested/region) assume an inherent age-sex structure to the harvest. This assumption will influence the total body mass of the harvested animal, in turn, dictating the edible weight yield; however, the assumed structure may be inconsistent with that of the local Inuit harvester context.

Second, the edible portions of different animal parts consumed as reported in the IHS were summed for each participant (e.g., caribou ribs + caribou meat) to yield an estimated total consumption by species. This approach assumes there is no specific preference for any particular animal part (e.g., beluga muktuk [skin]). As a result, the estimated harvest requirement may be underestimated if more animals are harvested to obtain certain preferable parts.

Third, the food preparation method will influence the moisture content and thus the resulting weight of country food consumed. Food frequency questionnaires of the IHS collected consumption data according to the relevant edible portion (e.g., beluga muktuk), at times embedding various preparation methods (e.g., fresh, cooked, or frozen) into the same grouping by edible portion. The moisture content of raw and cooked edible portions can differ by up to $10 \%$ (Kuhnlein et al., 1996). The difference in weight resulting from different cooking methods (e.g., baking vs. boiling) was deemed insignificant in relation to individual differences in consumption. When respondents reported consuming dried portions of country foods, however, we converted dry weights to fresh weights using moisture content differentials reported in the literature for caribou and beluga: raw caribou meat $=71 \mathrm{~g}$ moisture $/ 100 \mathrm{~g}$ portion; dried caribou meat $=32 \mathrm{~g}$ moisture $/ 100 \mathrm{~g}$ portion; dried beluga meat $=22 \mathrm{~g}$ moisture $/ 100 \mathrm{~g}$ portion; raw beluga muktuk $=68 \mathrm{~g}$ moisture $/ 100 \mathrm{~g}$ portion; raw beluga blubber $=22 \mathrm{~g}$ moisture $/ 100 \mathrm{~g}$ portion (Kuhnlein and Soueida, 1992). 
TABLE 1. Distribution of the population by age and sex in each of the five regions included in the Inuit Health Study.

\begin{tabular}{|c|c|c|c|c|c|c|}
\hline \multirow[b]{2}{*}{ Population } & \multicolumn{4}{|c|}{ Nunavut $^{1}$} & \multirow[b]{2}{*}{$\mathrm{ISR}^{2,4}$} & \multirow[b]{2}{*}{ Nunatsiavut $^{4}$} \\
\hline & Nunavut & Kivalliq $^{3}$ & Qikiqtaaluk $^{3}$ & Kitikmeot $^{3}$ & & \\
\hline $0-12$ years old & 8873 & 2688 & 4438 & 1743 & 1125 & 495 \\
\hline Male & 4538 & 1373 & 2268 & 890 & 555 & 270 \\
\hline Female & 4328 & 1318 & 2165 & 853 & 570 & 225 \\
\hline 13-17 years old & 3458 & 1028 & 1748 & 678 & 505 & 220 \\
\hline Male & 1773 & 518 & 903 & 350 & 250 & 115 \\
\hline Female & 1683 & 508 & 845 & 333 & 250 & 95 \\
\hline $18+$ years old & 19585 & 5235 & 10745 & 3600 & 4125 & 1895 \\
\hline Male & 10100 & 2695 & 5540 & 1855 & 2095 & 1000 \\
\hline Female & 9490 & 2540 & 5205 & 1745 & 2030 & 900 \\
\hline Total by region & 31905 & 8955 & 16940 & 6010 & 5775 & 2615 \\
\hline \multicolumn{7}{|c|}{ Aboriginal Identity ${ }^{5}$} \\
\hline Male & & 90 & 79 & 89 & 72 & 93 \\
\hline Female & & 91 & 82 & 90 & 75 & 90 \\
\hline
\end{tabular}

${ }^{1}$ The Nunavut totals represent the sum of data from the territory's three subregions: Kivalliq, Qikiqtaaluk, and Kitikmeot.

${ }^{2}$ ISR = Inuvialuit Settlement Region.

${ }^{3}$ Data from Statistics Canada, 2011 Census of Population - regional data. The regional totals are based on Statistics Canada data.

They do not represent our summation of the different age groups. Census totals are not intended to add up perfectly.

${ }^{4}$ Data from Statistics Canada, 2011 Census of Population - community data pooled by region.

${ }^{5}$ The percentage of respondents self-identifying as Aboriginal in the 2006 census community profiles.

Fourth, since the IHS did not collect data on country food consumption by Inuit younger than 18 years, we estimated child and adolescent food intake according to previous standards described by Berkes and Farkas (1978). We assumed that children $(0-12$ years) consumed one-third of adult consumption and adolescents (13-17 years), two-thirds. We adjusted the prevalence of country food consumption for children and adolescents to simulate their relatively lower intake of country food, assuming it to be $25 \%$ (children) and $75 \%$ (adolescents) of prevalence reported by adults in the IHS (Quinn et al., 2012).

Fifth, the country food requirements reported here assume that all available country food is consumed, with no consideration of consumer wastage. These results can thus be readily adjusted by an appropriate conversion factor to account for projected wastage losses at the consumer level.

Finally, the self-reported use of country food, as recorded in the food frequency questionnaire of the Inuit Health Survey of 2007-08, was used as a snapshot of baseline country food use among Inuit at that time. It is important to emphasize that this estimate does not represent preferred, ideal, or recommended diets to satisfy nutritional or cultural requirements for country food.

\section{RESULTS}

\section{Country Food Consumption}

On the basis of IHS food frequency questionnaire responses, we computed adult consumption equivalents $(\mathrm{kg} /$ person/year) for beluga whale, ringed seal, and caribou for both men and women in each of the five regions (Table 3 ). It must be noted that the median and 95th percentile consumption statistics reported in Table 3 are meaningful
TABLE 2. Edible yield of selected traditional mammals in edible $\mathrm{kg} /$ total live weight.

\begin{tabular}{|c|c|c|}
\hline \multirow[b]{2}{*}{ Species } & \multicolumn{2}{|c|}{ Edible yield } \\
\hline & Range $^{1}$ & Value used $^{2}$ \\
\hline Beluga whale & $106^{3}-481^{4}$ & $335^{5}$ \\
\hline Ringed seal & $13^{5}-59^{6}$ & $16^{7}$ \\
\hline Caribou & $36^{5}-50^{8}$ & $45^{9}$ \\
\hline \multicolumn{3}{|c|}{$\begin{array}{l}{ }^{1} \text { Range of edible weights reported in the literature. } \\
{ }^{2} \text { Value employed in the calculation of harvest requirements in } \\
\text { this paper. }\end{array}$} \\
\hline \multicolumn{3}{|c|}{$\begin{array}{l}\text { Sources: }{ }^{3} \text { Berger }(1977) ;{ }^{4} \text { Ewan Cotterhill and Associates (1986) } \\
\text { in Ashley (2002); }{ }^{5} \text { Usher }(2000) ;{ }^{6} \text { Pattimore (1985); }{ }^{7} \text { Value } \\
\text { based on average of Usher (2000) and Loring (1996); }{ }^{8} \text { Veitch } \\
(1996) ;{ }^{9} \text { Ashley }(2002) .\end{array}$} \\
\hline
\end{tabular}

in describing individual-level responses; however, the $95 \%$ $\mathrm{CI}$ of the mean is the most representative result from which to determine regional subsistence harvest requirements. A consistent trend observed across all regions was the high prevalence of caribou consumption, with no region reporting less than $94 \%$ prevalence. Caribou was also the country food consumed in the greatest quantities, with annual mean consumption ranges of $29.6-101.3 \mathrm{~kg} /$ person for women and 49.7-122.8 kg/person for men, depending on region (Table 3). Table 3 also shows regional differences in the pattern of country food use.

\section{Harvest Requirements}

Details of regional beluga whale, ringed seal, and caribou harvests required to satisfy contemporary Inuit diets are summarized in Table 4. Median and 95th percentile results describe regional harvests projected from 
the corresponding IHS individual-level consumer results, whereas the $95 \%$ CI of the mean provides the most likely harvest estimate for the region.

From mean country food consumption results reported in the IHS and the edible yield of $335 \mathrm{~kg}$ edible parts/beluga (Table 2), we calculate that an average beluga whale will provide the meat and muktuk for 17-57 women or 14-28 men, depending on region. In the scenario of highest beluga whale consumption considered here $(133.2 \mathrm{~kg} / \mathrm{man}$, the $95 \%$ percentile in the Inuvialuit Settlement Region), an average beluga whale will satisfy the dietary requirement of as few as three people annually. These consumption statistics, together with population demographics (Table 1) and average species edible yield (Table 2), suggest that mean regional requirements of the beluga whale harvest range from 59 whales per year in Kitikmeot to 313 in Qikiqtaaluk and 337 in Kivalliq (Table 4).

For ringed seal, using the edible yield of $16 \mathrm{~kg}$ edible parts/seal (Table 2), mean IHS consumption results suggest that a ringed seal will provide meat or organs for one to four women, depending on region. For men in regions with low levels of ringed seal consumption, one seal may satisfy the diet of slightly more than two men annually, but for regions of higher consumption, an average male consumer would require upwards of one and a half seals annually. In the scenario of highest consumption we considered $(81.1 \mathrm{~kg} /$ man, the $95 \%$ percentile in Qikiqtaaluk), an individual requires roughly five ringed seals each year. These consumption statistics indicate than mean regional harvest requirements range from 386 ringed seals per year in the Inuvialuit Settlement Region to 11687 ringed seals per year in Qikiqtaaluk (Table 4).

For caribou, using the representative edible yield of $45 \mathrm{~kg}$ edible parts/caribou, our results suggest that in regions of low caribou consumption, a caribou will satisfy the dietary need of one or two average men or women annually. However, in regions of higher consumption, an average individual would require two to three caribou annually. Consumption of caribou by individuals at the 95th percentile $(286.4 \mathrm{~kg} /$ person in Kivalliq and Kitikmeot) would require six or more caribou annually. These consumption statistics correspond to mean regional harvest requirements ranging from 1865 caribou per year in Nunatsiavut to 14270 caribou per year in Kivalliq (Table 4).

\section{DISCUSSION}

To our knowledge, this study represents the first systematic effort to estimate regional harvest requirements of country food across several Inuit regions of northern Canada. Most of the previous initiatives estimated basic Inuit harvest needs using data reported by harvesters (see for instance Miller, 1983; Jingfors, 1986). Estimates by the Federal Court of Canada suggest that Inuit require between five and seven caribou per person each year (Miller, 1983). Similar estimates by Jingfors (1986) suggest a slightly lower annual requirement of 3.1 caribou per person. Harvest estimates may be converted to edible food weights to yield the "potential" edible yield (see Berkes et al., 1994); however, the actual consumption often remains unknown (Ashley, 2002). Furthermore, the accuracy of this conversion has scarcely been validated through concurrent dietary studies (Guyot, 2006). Moreover, harvester-recall methods may yield lower estimates of country food use compared to the amounts of country food reported in dietary recalls and food frequency interviews, especially for smaller and non-staple species (Guyot, 2006). Despite considerable effort to characterize wildlife harvests for various Aboriginal groups across northern Canada, seldom have these harvests been documented within the context of their contribution to diet (Berkes and Farkas, 1978; Berkes et al., 1994). Existing harvest data sets, moreover, have traditionally suffered from a lack of systematic sampling techniques, and being derived almost exclusively from harvesters, they suffer from inherent methodological limitations, namely, the influence of "strategic bias" and harvester recall failure (for a review, see Usher and Wenzel, 1987). The current approach of estimating harvest requirements for country food on the basis of food use patterns should provide results that are more relevant to the context of food security.

Our estimated harvest requirements are based exclusively on dietary consumption and do not consider requirements for trade, sale, and sport. Omission of economic harvests may result in an underestimation of total regional harvest requirements; therefore, it is important that the results presented here be understood within the exclusive context of harvest for country food use. Table 5 compares our country food estimates with results reported in two regional harvest surveys. Although the data were collected in different years and different methods were used, the comparison provides a crude validation of our estimates. It is remarkable that the ranges reported in previous harvest surveys are very similar to our estimates, and many even fall within the $95 \%$ CI of our estimated mean (Table 5). Our estimates are based on an individual's recall of food use over the previous year and therefore do not reflect the desire, or actual need, of the individual. A low consumption rate may reflect limited country food availability in the household, rather than inherent dietary preference. Indeed, the food frequency questionnaire of the Inuit Health Survey identified a lower intake (daily frequency of consumption) of country food among food insecure participants (Huet et al., 2012). Thus, results presented here must be understood as relevant to reported diets, rather than to desired or optimal diets. More fundamentally, inherent limitations exist in the use of health survey data (e.g., the order in which questionnaires are administered, questionnaire length, misinterpretation of questions by participants), and the use of the food frequency questionnaire to estimate country food consumption (e.g., recall bias, estimation of portion sizes) (Duhaime et al., 2002; Pakseresht and Sharma, 2010). Despite its systematic 


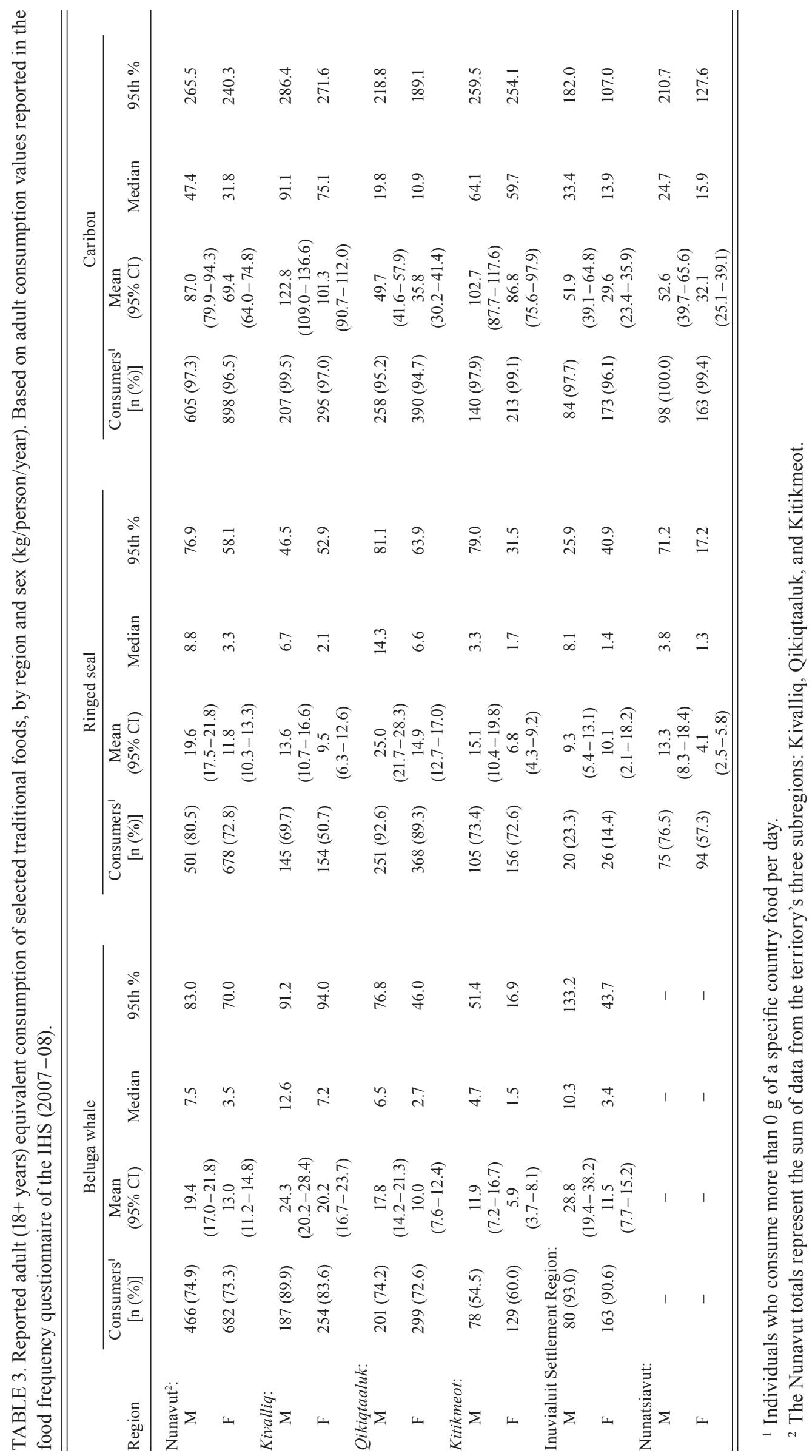




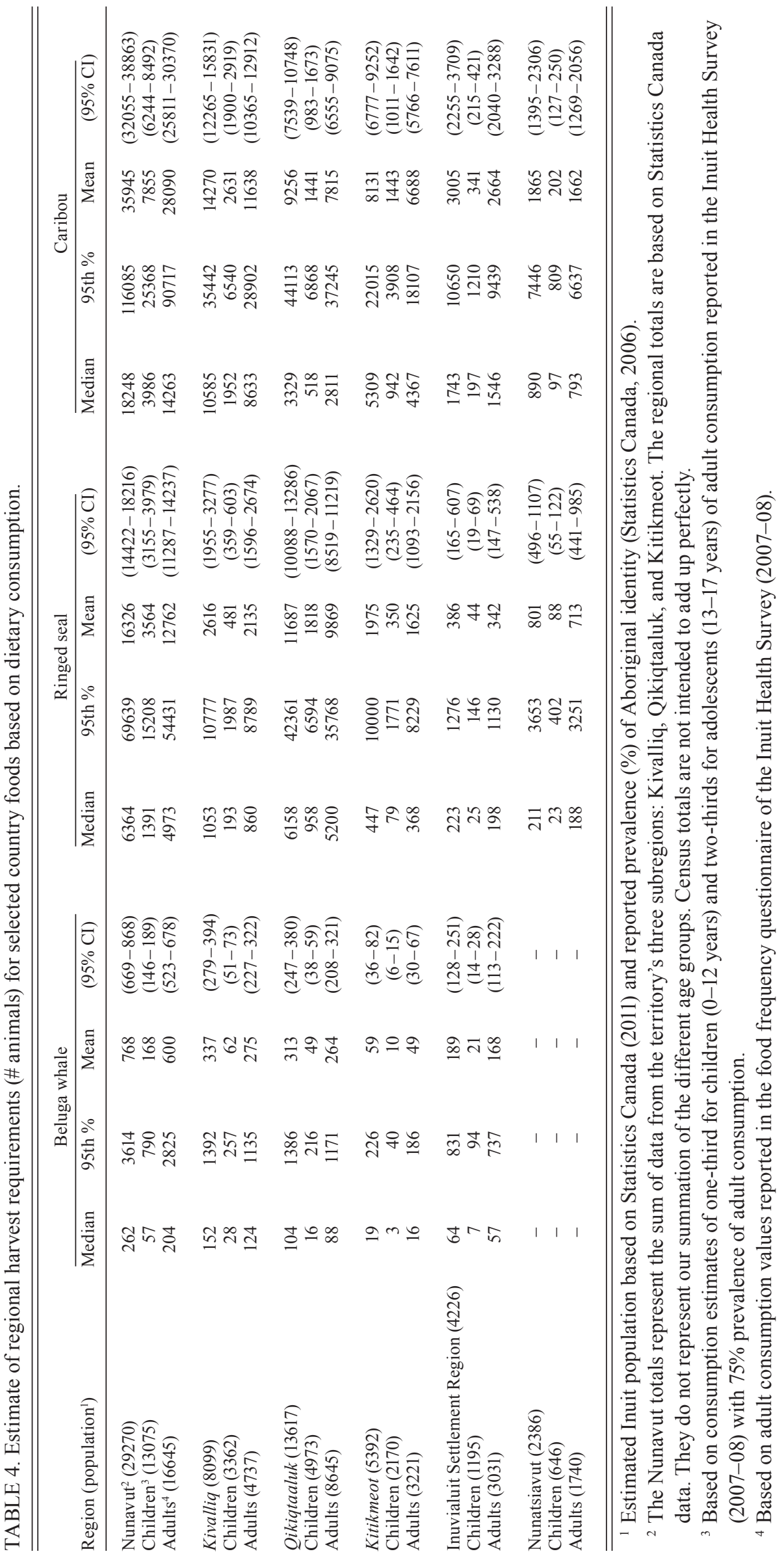


TABLE 5. Comparison of harvest estimates from this study ${ }^{1}$ and annual harvest estimates reported in the Nunavut Wildlife Harvest Study ${ }^{2}$ and the Inuvialuit Harvest Study ${ }^{3}$.

\begin{tabular}{|c|c|c|c|c|c|c|}
\hline Nunavut $^{2}$ & 679 & $669-868$ & 25086 & $14422-18216$ & 24522 & $32055-38863$ \\
\hline Qikiqtaaluk & 248 & $247-380$ & 23048 & $10088-13286$ & 10440 & $7539-10748$ \\
\hline Kitikmeot & $7^{4}$ & $36-82$ & 840 & $1329-2620$ & 4089 & $6777-9252$ \\
\hline Inuvialuit Settlement Region ${ }^{3}$ & 130 & $128-251$ & 1085 & $165-607$ & 3113 & $2040-3288$ \\
\hline
\end{tabular}

$195 \%$ CI of estimated mean.

${ }^{2}$ Priest and Usher (2004): five-year average (1996-2001).

${ }^{3}$ Usher and Wendt (1999): 10-year average (1988-97).

${ }^{4}$ Many Kitikmeot communities reported no beluga harvest data in the five study years.

errors regarding consumption frequency and serving size (Bogers et al., 2003), researchers still regard the food frequency questionnaire as a valid and reproducible tool for estimating long-term diet (Willet et al., 1985; Silva et al., 2013), including the diet of the Inuit population (Duhaime et al., 2002; Pakseresht and Sharma, 2010).

The key factor used for the conversions of dietary consumption to harvest requirements is the mean edible weight for each species (Table 2). However, harvest data sets have often been incomplete, inconsistent, and poorly reported, without reference to location, season, sample size, or sample type (Ashley, 2002). Moreover, many wildlife edible weight estimates have been based on average adult weights from sports hunters (Berger, 1977; Ashley, 2002), whereas the size and weight of animals harvested by Inuit may reflect preferential harvest selection or opportunity and encounter. Additionally, many species exhibit an inherently large range in the reported edible weight yield (Ashley, 2002). Sources of variance in edible weight estimates have been previously reviewed (Usher, 2000). Notably, whole body weights and body composition of animals can vary substantially by year, season, life-cycle stage, and geographic location (Berger, 1977), and this is especially true of Arctic animals, who build up fat reserves in one season and deplete them in the next. The blubber content of ringed seals, for instance, may range from $31 \%$ to $51 \%$ of total body weight over the year (Ryg et al., 1990).

In accord with previous studies, we found that country food remains an integral dimension of the contemporary Inuit diet (Duhaime et al., 2002; Kuhnlein et al., 2004), with consumption of more than 88 traditional food items (species and parts) reported (data not presented). Our results reaffirm the role of caribou as a staple food of the Inuit diet: it was the food consumed most frequently and in greatest quantities across all regions (Table 3). Mean annual caribou consumption (range $=29.6-122.8$, Table 3) is higher in all Inuit Health Survey regions than the 19.9 $\mathrm{kg} /$ person previously reported for the Nunavik region by Duhaime et al. (2002). Differences in patterns of country food use across regions are complex and can be attributed to a number of cultural, socio-economic, political, environmental, and biological factors that govern the preference, availability, and accessibility of country food for harvest and consumption (Natcher et al., 2011). The conservative approach that we used in our assumptions will likely result in an overestimate of the number of animals required. Our Inuit partners also cautioned that the reported food use reflected the abundance of the species only in the year (or the previous year) of the study. It is important to consider the large annual fluctuations in the availability of wildlife species. Multiple sources of information need to be collected and cross-referenced to provide the most reliable estimate of harvest requirements specific to each region. Traditional knowledge is also important to be included in harvest management.

The rapid environmental changes in the Arctic have resulted in a decline of availability of country food that can have significant impact on the quality of the Inuit diet (Rosol et al., 2016). Local governments, supported by an established body of literature, have advocated the use of country foods as an effective strategy for promoting healthy lifestyles, nutritious diets, and food security in the Arctic (Aarluk Consulting Incorporated, 2006; Chan et al., 2006). While it has been postulated that the food requirements of northern Aboriginal families can be satisfied principally by local sources (Paci et al., 2004), no research presently exists to substantiate whether this notion is intrinsically possible or ecologically sustainable. Our results provide a basis to evaluate the sustainability of Inuit subsistence harvests, particularly when interpreted in the context of available wildlife population data, and they can be used to develop informed conservation policies.

It is clear that wildlife managers, harvesters, country food consumers, and health and nutrition professionals are mutually relevant. However, there is a pronounced ideological dichotomy or lack of common data platforms for human nutrition and food security information and wildlife population information. Our results may provide additional insights to help communities, public health workers, and wildlife organizations develop sustainable food security initiatives in the North. Future management strategies related to country food species in the Arctic will be most likely to succeed if they incorporate the needs and preferences for country food directly expressed by each 
community and are articulated within a context that is relevant to both the wildlife management and public health sectors. It is clear that further research is needed both to clarify the effects of harvest restrictions on Inuit food security and to quantify the stress that subsistence harvests place on wildlife populations.

\section{ACKNOWLEDGEMENTS}

We wish to recognize and extend our appreciation to all participants who consented to participate in the Canadian IPY IHS, all supporting community and health organizations, nurses, technicians, and IHS staff, as well as the steering committees representing three Inuit land-claim regions, for guiding and making the survey possible. We also wish to thank the New Inuit Health Survey Working Group, as well as the three anonymous reviewers, for reviewing the manuscript and imparting invaluable feedback. The Inuit Health Survey was realized with funding from the Government of Canada Federal Program for the International Polar Year, Canadian Institutes of Health Research, Health Canada, Indian and Northern Affairs Canada, the Government of Nunavut, ArcticNet, the Canada Research Chair Program, and the Canadian Foundation for Innovation. The authors acknowledge funding support from ArcticNet (to H.-M. Chan) and the Nasivvik Centre (to T.-A. Kenny).

\section{REFERENCES}

Aarluk Consulting Incorporated. 2006. A consultation-based review of the harvester support programs of the Government of Nunavut and Nunavut Tunngavik Inc. Iqaluit: Aarluk Consulting Incorporated. $91 \mathrm{p}$.

Ashley, B. 2002. Edible weights of wildlife species used for country food in the Northwest Territories and Nunavut. Manuscript Report No. 138. Yellowknife: Department of Resources, Wildlife and Economic Development, Government of the Northwest Territories.

Bennett, E.L., Blencowe, E., Brandon, K., Brown, D., Burn, R.W., Cowlishaw, G., Davies, G., et al. 2007. Hunting for consensus: Reconciling bushmeat harvest, conservation, and development policy in West and Central Africa. Conservation Biology 21(3):884-887.

https://doi.org/10.1111/j.1523-1739.2006.00595.x

Berger, T. 1977. Northern frontier, northern homeland: The report of the Mackenzie Valley Pipeline Inquiry: Volume Two. Ottawa: Minister of Supply and Services Canada. 273 p.

Berkes, F., and Farkas, C.S. 1978. Eastern James Bay Cree Indians: Changing patterns of wild food use and nutrition. Ecology of Food and Nutrition 7(3):155-172. https://doi.org/10.1080/03670244.1978.9990526

Berkes, F., George, P.J., Preston, R.J., Hughes, A., Turner, J., and Cummins, B.D. 1994. Wildlife harvesting and sustainable regional Native economy in the Hudson and James Bay Lowland, Ontario. Arctic 47(4):350-360.

https://oi.org/10.14430/arctic1308
Blanchet, C., and Rochette, L. 2008. Qanuippitaa? How are we? Nutrition and food consumption among the Inuit of Nunavik. Institut national de santé publique du Québec and Nunavik Regional Board of Health and Social Services.

http://www.inspq.qc.ca/pdf/publications/nunavik.asp

Bogers, R.P., Dagnelie, P.C., Westerterp, K.R., Kester, A.D.M., van Klaveren, J.D., Bast, A., and van den Brandt, P.A. 2003. Using a correction factor to correct for overreporting in a foodfrequency questionnaire does not improve biomarker-assessed validity of estimates for fruit and vegetable consumption. The Journal of Nutrition 133(4):1213-1219.

Borré, K. 1991. Seal blood, Inuit blood, and diet: A biocultural model of physiology and cultural identity. Medical Anthropology Quarterly 5(1):48-62.

https://doi.org/10.1525/maq.1991.5.1.02a00080

Campbell, M. 2007. Wildlife research in the Kivalliq Region of Nunavut with implications to the needs of Nunavummiut. Final Wildlife Report No. 18. Iqaluit: Department of Environment, Government of Nunavut.

Chan, H.M., Fediuk, K., Hamilton, S., Rostas, L., Caughey, A., Kuhnlein, H., Egeland, G., and Loring, E. 2006. Food security in Nunavut, Canada: Barriers and recommendations. International Journal of Circumpolar Health 65(5):416-431. https://doi.org/10.3402/ijch.v65i5.18132

Chapin, F.S., III, Peterson, G., Berkes, F., Callaghan, T.V., Angelstam, P., Apps, M., Beier, C., et al. 2004. Resilience and vulnerability of northern regions to social and environmental change. AMBIO: A Journal of the Human Environment 33(6): 344-349. https://doi.org/10.1579/0044-7447-33.6.344

Condon, R.G., Collings, P., and Wenzel, G. 1995. The best part of life: Subsistence hunting, ethnicity, and economic adaptation among young adult Inuit males. Arctic 48(1):31-46. https://doi.org/10.14430/arctic1222

Cooney, R. 2004. The precautionary principle in biodiversity conservation and natural resource management: An issues paper for policy-makers, researchers and practitioners. IUCN Policy and Global Change Series No. 2. Gland, Switzerland: IUCN.

DFO (Fisheries and Oceans Canada). 2000. Eastern Beaufort Sea beluga whales. DFO Science Stock Status Report E5-38. Ottawa: DFO.

Diduck, A., Bankes, N., Clark, D., and Armitage, D.R. 2005. Unpacking social learning in social-ecological systems: Case studies of polar bear and narwhal management in northern Canada. In: Berkes, F., Huebert, R., Fast, H., Manseau, M., and Diduck, A., eds. 2005. Breaking ice: Renewable resource and ocean management in the Canadian North. Calgary: University of Calgary Press. 269-290.

Duhaime, G., Chabot, M., and Gaudreault, M. 2002. Food consumption patterns and socioeconomic factors among the Inuit of Nunavik. Ecology of Food and Nutrition 41(2):91 - 118. https://doi.org/10.1080/03670240214491

Dumond, M. 2007. Western Kitikmeot Caribou Workshop. Final Wildlife Report No. 19. Iqaluit: Department of Environment, Government of Nunavut. $47 \mathrm{p}$. 
Egeland, G.M., Johnson-Down, L., Cao, Z.R., Sheikh, N., and Weiler, H. 2011. Food insecurity and nutrition transition combine to affect nutrient intakes in Canadian Arctic communities. The Journal of Nutrition 141(9):1746-1753. https://doi.org/10.3945/jn.111.139006

Ewan Cotterhill and Associates. 1986. Arctic compensation study: 213. Prepared for Department of Indian Affairs and Northern Development.

Government of Newfoundland and Labrador. 2013. Hunting ban announced on George River caribou herd. 28 January 2013, News Release. http://www.releases.gov.nl.ca/releases/2013/env/0128n08.htm

Government of Nunavut. 2015a. Increased TAH limit for Southampton Island caribou. 15 December 2015, Public Service Announcement, Department of Environment. http://www.gov.nu.ca/environment/news/increased-tah-limitsouthampton-island-caribou

___ 2015b. Limited caribou harvest allowed on Baffin Island. 26 August 2015, News Release, Department of Environment. http://www.gov.nu.ca/environment/news/limited-caribouharvest-allowed-baffin-island

Gosselin, J.-F., Lesage, V., Hammill, M.O., and Bourdages, H. 2002. Abundance indices of beluga in James Bay, eastern Hudson Bay and Ungava Bay in summer 2001. Canadian Science Advisory Secretariat Research Document 2002/042. Ottawa: Fisheries and Oceans Canada. 27 p.

Guyot, M. 2006. Impacts of climate change on traditional food security in Aboriginal communities in northern Canada. MSc thesis, School of Dietetics and Human Nutrition, McGill University, Montreal, Quebec.

Huet, C., Rosol, R., and Egeland, G.M. 2012. The prevalence of food insecurity is high and the diet quality poor in Inuit communities. The Journal of Nutrition 142(3):541 - 547. https://doi.org/10.3945/jn.111.149278

Hummel, M., and Ray, J.C. 2008. Caribou and the North: A shared future. Toronto: Dundurn Press.

Jingfors, K. 1986. Inuit harvesting levels of caribou in the Kitikmeot Region, Northwest Territories, Canada, 1982-1984. Rangifer 6 (Special Issue No. 1):167-172. https://doi.org/10.7557/2.6.2.642

Kilabuk, P. 1998. Final report on a study of Inuit knowledge of the Southeast Baffin beluga. Iqaluit: Nunavut Wildlife Management Board.

Kuhnlein, H.V., and Receveur, O. 2007. Local cultural animal food contributes high levels of nutrients for Arctic Canadian Indigenous adults and children. The Journal of Nutrition 137(4):1110-1114.

Kuhnlein, H.V., and Soueida, R. 1992. Use and nutrient composition of traditional Baffin Inuit foods. Journal of Food Composition and Analysis 5(2):112-126. https://doi.org/10.1016/0889-1575(92)90026-G

Kuhnlein, H.V., Soueida, R., and Receveur, O. 1996. Dietary nutrient profiles of Canadian Baffin Island Inuit differ by food source, season, and age. Journal of the Academy of Nutrition and Dietetics 96(2):155-162.

https://doi.org/10.1016/S0002-8223(96)00045-4
Kuhnlein, H.V., Receveur, O., Soueida, R., and Egeland, G.M. 2004. Arctic Indigenous peoples experience the nutrition transition with changing dietary patterns and obesity. The Journal of Nutrition 134(6):1447-1453.

Kutz, S.J., Checkley, S., Simard, M., Soos, C., Black, S., and Duignan, P. 2013. The need for a sustainable Arctic Wildlife Health Observation Network.

http://www.arcticobservingsummit.org/aos-2013-white-papers

Lambden, J., Receveur, O., and Kuhnlein, H.V. 2007. Traditional food attributes must be included in studies of food security in the Canadian Arctic. International Journal of Circumpolar Health 66(4):308-319. https://doi.org/10.3402/ijch.v66i4.18272

Loring, E. 1996. The cost-benefit relations of modern Inuit hunting: The Kapuivimiut of Foxe Basin, N.W.T. Canada. MA thesis, Department of Geography, McGill University, Montreal, Quebec.

Miller, F.L. 1983. Restricted caribou harvest or welfare northern Native's dilemma. In: Pulliainen, E., ed. Proceedings of the Third International Theriological Congress, Helsinki, 1982. VII. Third International Reindeer/Caribou Symposium, Saariselkä, 23-26 August 1982. Acta Zoologica Fennica 175:171- 175 .

Natcher, D.C., Felt, L., Chaulk, K., Procter, A., and the Nunatsiavut Government. 2011. Monitoring the domestic harvest of migratory birds in Nunatsiavut, Labrador. Arctic 64(3):362-366. https://doi.org/10.14430/arctic4125

Natcher, D.C., Felt, L., McDonald, J., and Ford, R. 2012. The social organization of wildfood production in Postville. In: Natcher, D.C., Felt, L., and Procter, A., eds. Settlement, subsistence, and change among the Labrador Inuit: The Nunatsiavummiut experience. Winnipeg: University of Manitoba Press. 171-188.

Nunavut Final Agreement. 1993. Agreement between the Inuit of the Nunavut Settlement Area and her Majesty the Queen in Right of Canada. Ottawa: Indian Affairs and Northern Development Canada and the Tunngavik Federation of Nunavut.

Nuttall, M., Berkes, F., Forbes, B., Kofinas, G., Vlassova, T., and Wenzel, G. 2005. Hunting, herding, fishing and gathering: Indigenous peoples and renewable resource use in the Arctic. In: Arctic Climate Impact Assessment: Scientific report. 649-690.

Paci, C.D.J., Dickson, C., Nickels, S., Chan, L., and Furgal, C. 2004. Food security of northern Indigenous peoples in a time of uncertainty. In: 3rd Northern Research Forum Open Meeting: The Resilient North-Human Responses to Global Change, 15-18 September 2004, Yellowknife and Rae Edzo, Northwest Territories.

Pakseresht, M., and Sharma, S. 2010. Validation of a quantitative food frequency questionnaire for Inuit population in Nunavut, Canada. Journal of Human Nutrition and Dietetics 23(s1):67-74. https://doi.org/10.1111/j.1365-277X.2010.01104.X

Pattimore, J.H. 1985. Inuit wildlife harvest for 1984 in the Baffin Region. Frobisher Bay: Baffin Regional Inuit Association. $10 \mathrm{p}$. 
Priest, H., and Usher, P.J. 2004. The Nunavut wildlife harvest study: Final report. Iqaluit: Nunavut Wildlife Management Board.

Quinn, C.L., Armitage, J.M., Breivik, K., and Wania, F. 2012. A methodology for evaluating the influence of diets and intergenerational dietary transitions on historic and future human exposure to persistent organic pollutants in the Arctic. Environment International 49:83-91. https://doi.org/10.1016/j.envint.2012.08.014

Rochette, L., and Blanchet, C. 2007. Qanuippitaa? How are we?: Methodological report. Québec: Institut national de santé publique du Québec and Nunavik Regional Board of Health and Social Services.

https://www.inspq.qc.ca/pdf/publications/692_esi methodological_report.pdf

Rosol, R., Powell-Hellyer, S., and Chan, H.M. 2016. Impacts of decline harvest of country food on nutrient intake among Inuit in Arctic Canada: Impact of climate change and possible adaptation plan. International Journal of Circumpolar Health 75: 31127 https://doi.org/10.3402/ijch.v75.31127

Ryg, M., Smith, T.G., and Øritsland, N.A. 1990. Seasonal changes in body mass and body composition of ringed seals (Phoca hispida) on Svalbard. Canadian Journal of Zoology 68(3):470-475. https://doi.org/10.1139/z90-069

Saudny, H., Leggee, D., and Egeland, G. 2012. Design and methods of the Adult Inuit Health Survey 2007-2008. International Journal of Circumpolar Health 71: 19752. https://doi.org/10.3402/ijch.v71i0.19752

Silva, N.F., Sichieri, R., Pereira, R.A., Silva, R.M.V.G., and Ferreira, M.G. 2013. Reproducibility, relative validity and calibration of a food frequency questionnaire for adults. Cadernos de Saude Publica 29(9):1783-1794.

Statistics Canada. 2006. 2006 census of population: Aboriginal peoples.

https://www12.statcan.gc.ca/census-recensement/2006/rt-td/ ap-pa-eng.cfm
2011. Census profile.

https://www12.statcan.gc.ca/census-recensement/2011/dp-pd/ prof/index.cfm?Lang=E

Stewart, D.B., and Lockhart, W.L. 2005. Chapter 14: Harvesting. In: An overview of the Hudson Bay marine ecosystem. Canadian Technical Report of Fisheries and Aquatic Sciences No. 2586. Ottawa: Fisheries and Oceans Canada. http://www.dfo-mpo.gc.ca/Library/314704-Ch14.pdf

Usher, P.J. 2000. Standard edible weights of harvested species in the Inuvialuit Settlement Region. Report to the Northern Contaminants Program, Ottawa: Department of Indian Affairs and Northern Development.

Usher, P.J., and Wendt, M.A. 1999. Inuvialuit Harvest Study Statistical assessment of the Harvest Survey Data Base, 1988-1996. Inuvik, Northwest Territories: Inuvialuit Harvest Study.

Usher, P.J., and Wenzel, G. 1987. Native harvest surveys and statistics: A critique of their construction and use. Arctic 40(2):145- 160 . https://doi.org/10.14430/arctic1759

Veitch, A. 1996. Economic value of ungulate harvest to the Sahtu Settlement Area. Norman Wells, Northwest Territories: Department of Resources, Wildlife and Economic Development.

Wein, E.E., and Freeman, M.M.R. 1992. Inuvialuit food use and food preferences in Aklavik, Northwest Territories, Canada. Arctic Medical Research 51(4):159-172.

Wilder, M. 1995. Quota systems in international wildlife and fisheries regimes. The Journal of Environment \& Development 4(2):55- 104.

https://doi.org/10.1177/107049659500400204

Willett, W.C., Sampson, L., Stampfer, M.J., Rosner, B., Bain, C., Witschi, J., Hennekens, C.H., and Speizer, F.E. 1985. Reproducibility and validity of a semiquantitative food frequency questionnaire. American Journal of Epidemiology 122(1):51-65. 